\title{
New York City Mastodons: Big Apple Tusks
}

\author{
Sidney Horenstein
}

Published online: 21 February 2008

(C) Springer Science + Business Media, LLC 2008

Keywords Mastodon · New York City · Manhattan . Brooklyn · Germany · Wooster Beach · Charles Willson Peale · John Warren

Unlike some cities, New York is not known as a locality for fossils, and for good reason, they are few and far between, especially if you exclude the treasure trove of fossils embedded in the dimension stone of facades, lobbies, and rest rooms.

It is easy to understand why New York City offers such a paucity of naturally occuring specimens when you consider that most of the city's bedrock is composed of high-grade metamorphics - gneiss, marble, and schist-1.1 billion to 435 million years old (Baskerville 1994). Any fossils that may have existed in the original parent rock have been destroyed by ensuing high-grade metamorphism, a process by which rocks are altered by heat and/or pressure. The only exposed sedimentary rocks are Cretaceous-age clays and sands. In the past, they have yielded plant fragments including lignite and a few invertebrates (Hollick 1908) and some microfossils, but these exposures are substantially diminished with continuing urbanization. However, almost the entire city has been glaciated, and in places the veneer of glacially transported rocks yield a variety of Paleozoic invertebrate fossils delivered from north and west of the city (Hollick 1893). But it also turns out that late glacial and/or early post glacial sediments contain relatively rare fragments of mastodon skeletons - the ice-age elephant (Mammut americanum) - and finding them is a hit-or-miss undertaking.

S. Horenstein $(\bowtie)$

American Museum of Natural History,

79th Street., Central Park West,

New York, NY, USA

e-mail: horenst@amnh.org
I have chosen the mastodon for this discussion, focusing on New York City as an unusual locality, because mastodon fossils are well distributed throughout North America, its fossils have been collected by the thousands (Haynes 1991), and mastodons were the rage long before dinosaurs were discovered.

The fact that these animals roamed what is now Broadway is an excellent example for starting a discussion on climatic change as well as the hot topic of what caused the demise of the charismatic late Pleistocene megafauna and, as we will see, introducing some aspects of the history of paleontology. Another purpose of this paper is to show that the study of paleontology and evolution can and should be interdisciplinary and multidisciplinary. Often, it is the secondary aspects of these subjects that can excite students and gain their interest.

Based on the plant material associated with mastodon fossils in northeastern United States, the mastodons clearly lived in spruce forests and open spruce woodlands containing swamps and bogs. Although the stratigraphic record is not very good for New York City localities, it can be assumed that they lived in a similar vegetation zone, an environment so different than the eastern deciduous forest that exists now in New York City. Today, there are remnants of this forest still extant, not only altered by many introduced species, but also not a true virgin forest because during the occupation by British and Hessian armies during the American Revolution the forests were entirely cut down on Manhattan Island to provide firewood and construction materials. The forest of the present time reestablished itself in many places with the withdrawal of the foreign troops.

As most of the glacial deposits are covered by buildings or located in the adjacent waterways that make New York City an archipelago, finding fossils requires diligence at construction sites where, in general, the focus has been on 
what is revealed in the bedrock rather than the superficial surface materials. After all, "dirt" is just dirt. As you will see, most of the specimens were found in the city in construction projects. Observing and investigating construction sites can be a rewarding project, but how close you can get to the excavation varies considerably from community to community, and local conditions have to be assessed. Sometimes the best that can be done is to observe with a pair of binoculars. As many of the mastodons have been found in swamp and bog deposits, a likely place is to look for construction sites situated where bogs exist or have been covered over. Historical maps can provide crucial information; for example, the Viele Map (Viele 1865) in New York City. In addition, www.davidrumsey.com/ maps6128.html, provides such information.

The first recorded discovery of a mastodon in New York City occurred on Long Island in 1858, in an area that is now in the borough of Queens, when it was uncovered during the construction of a reservoir for the water supply of the then City of Brooklyn. The discovery was made just a year before Darwin published his masterful work The Origin of the Species and the same year the first nearly complete dinosaur, a hadrosaur, was found in the United States in Haddonfield, New Jersey.

The resulting reservoir, Baisley Pond, is no longer used for that purpose and is now a unit of the New York City Department of Parks (New York City Department of Parks 2001). To create the reservoir, the City of Brooklyn employed about 100 men to dig out the spongy peaty material, and, while this work was being carried out, part of a mastodon skeleton was exposed. It received quite a lot of publicity, and as a result some of the workmen hid a few of the teeth in their shanties believing that they were monetarily valuable. As digging progressed, more teeth were unearthed and were described as being in a perfect state of preservation, black in color and glossy. Other parts of the skeleton, including most of the skull, were discarded and buried under the excavated soil. To commemorate this ancient citizen, the Parks Department had a life-size plastic mastodon model constructed for children to play on in the southwestern part of the park. It can be easily seen in the $3 \mathrm{D}$ version of Microsoft's Live Search, http://maps.live.com, but cannot be seen on the Google Earth web site, http://earth.google.com.

One of the persons attracted to the site was Wooster Beach, M.D. When he arrived at the nearby town of Jamaica, he stopped at a hotel and found that the owner already was in possession of one of the teeth which Beach confirmed as being from a mastodon. He had no difficulty identifying the fossil in view of the fact that it matched several teeth he owned that were displayed in his Anatomical Museum located at 414 Broadway (Beach 1858).

Before I continue, a few words to place this physician in the history of medicine: Dr. Beach was in the forefront of a reform movement in medicine that proposed to teach every person about human anatomy and physiology to improve health and prevent disease. To that end, his Anatomical Museum contained exhibits of the human body as well as fossils and other animal displays. He preached that most diseases would respond more readily to nature's remedies, such as roots and herbs. His The American Practice of Medicine was very popular and the 1852 edition contained many hand-colored plates. The book was the first compendium of medical practice published in America in which pathological changes were correlated with disease processes (Van Brimmer 1999).

At this point in the narrative, we need to take another diversion and see what relationship Dr. Beach had with mastodons. George Gaylord Simpson (1942) as well as many others described the discovery and excavation of a mastodon skeleton found in 1799 in Orange County, New York (see www. ansp.org/museum for excellent web pages on mastodons and what follows here) as historically significant and one of the most important of all fossils discovered in the United States. It was collected in 1801 by Charles Willson Peale and others, restored and mounted and exhibited in Peale's Museum in Philadelphia. It was the first complete fossil mastodon discovered and the first fossil of any kind to be articulated and exhibited in America. In fact, Peale created the first natural history museum in North America (Yochelson 1992, p.488), and was the first to create a habitat group - a prelude to the museum diorama (Yochelson 1992, p. 490), and was the first to mount a scientific expedition (to dig up the mastodon) (Yochelson 1992, p. 496). The museum came to be, with Niagara Falls, one of the nation's great attractions (Sellers 1980, p. 300).

Simpson (1942, p. 161) describes the events that followed. "After C. W. Peale's death his Philadelphia Museum, which had started as a serious and scientific institution despite its commercial aspects, succumbed to the meretricious influences that affected many such exhibits around and after 1840, became a glorified penny arcade, and eventually sold to P.T. Barnum. The historic first mastodon skeleton was destroyed by fire in one of that showman's dime exhibits."

At the time is was not known whether it was destroyed in Barnum's Philadelphia Museum, which burned down in 1850, or his American Museum (not the American Museum of Natural History), which met the same fate in 1865. As a result, historians and paleontologists always assumed that the Philadelphia mastodon skeleton was destroyed in one of the fires. However, George Gaylord Simpson and H. Tobien (1954) have shown that the specimen exists today in Darmstadt, Germany in the Hessisches Landesmuseum for which it was purchased by J.J. Kaup in 1854.

Part of Kaup's internal report, translated in Simpson and Tobien (1954), explains that the specimen was shipped to 
Europe by speculators (italics, mine) to be sold to King Louis Philippe for 100,000 francs, who planned to give it to the Jardin des Plantes. Too late: it was 1848, and just as the mastodon arrived the king was already fleeing to England after abdicating. Undaunted, speculators then brought the specimen to London where it was offered to the British Museum, but alas, too late again: the museum had already purchased a skeleton a short time before. It was offered to other institutions in London, but again there were no takers. So it was exhibited in several places in London for a fee, but few came because a similar skeleton could now be seen for free at the British Museum. It was in 1854 that the specimen was purchased, and Kaup's report indicated what a bargain it was. This aspect of the transfer to Germany, that speculators sold it, has been repeated often. For example, Sellers (1980, pp 309-310) indicates that the mammoth was on display from February 2 to March 4, 1848 and that a catalogue for the sheriff's sale of the museum contents printed on June 8 did not list the mastodon. "It had already been sent abroad for sale." More recently, Paul Seronim states in his important and extensive study of the historical significance of mastodons, American Monster (2000, p. 402), that "In the Summer of 1848, with Peale's Philadelphia Museum on the brink of bankruptcy, the mastodon skeleton was sent to Europe by speculators to be auctioned off to the highest bidders."

So who was (were) the speculator(s)? It was none other than our Dr. Beach. "I purchased the skeleton [when Peale's museum in Philadelphia was broken up] and had it mounted in the Anatomical Museum, when located in the Bowery, in this city" (Beach 1858). When he learned the French government was interested in purchasing the skeleton, he packed it up and transported to Paris where it was mounted in the Elysian Garden near the Palais Royale awaiting the sale. Because the king abdicated and therefore there could be no sale, Beach then shipped it to London and had it remounted where it "was looked upon as a monument of antiquity and natural curiosity." Dr. Beach stated that "this specimen should have been retained by our government for the National Museum. I sent a petition to that effect, but failed in accomplishing the object in view." He ended with "this communication, I presume will not be uninteresting to the lovers of science or natural history" (Beach 1858).

Perhaps the first mastodon dug up on Manhattan Island was reported in Cozzens 1843 (p. 75), which states that "The cellular part of a large bone, probably of the mastodon, was found in digging the cellar of J.M. Bradhurst's house about $10 \mathrm{ft}$ below the present surface, in Broadway near Franklin Street." An examination of the Viele Map shows that the location was on a filled wetland.

Manhattan's first definitive mastodon fossil, a tusk, was exposed in Inwood, today its northernmost neighborhood, during April 1885 at Dyckman Street near Broadway. The site is now the Lt. William Tighe Triangle, a small park formed by the intersection of Riverside Drive, Dyckman Street, and Broadway, but in 1885, it was near the western end of great freshwater and saltwater marshes that stretched westward from the Harlem River. Elijah A. Howland, a public school principal, found the tusk in a drainage ditch being cut through a peat bog. He brought the specimen, about 15 in. long and 4 in. in diameter, to the American Museum of Natural History for identification, and then kindly left it as a gift. The tusk had been broken; it was probably much longer when originally found and then damaged during the excavation work (Hartnagel and Bishop 1922 p. 39). One can only speculate whether this tusk was in any way connected (perhaps literally) to the jaw found down the street 40 years later.

The second specimen, another tusk, was presented to the Museum in 1891 by Lt. Col. George L. Gillespie of the Corps of Engineers. It was found during the excavation of the Harlem Ship Canal, which was dug to make the shallows of the Harlem River navigable from the East River to the Hudson. (In the process, the course of the Harlem River was changed; the northernmost tip of Manhattan Island, Marble Hill, was severed by the new canal and became part of the mainland, on the Bronx side of the reshaped river.) Its purpose was to provide a second entrance to the port of New York and a direct route to the Atlantic Ocean by way of Long Island Sound. The tusk was found $16 \mathrm{ft}$ below the mean low-water level. Although partly damaged by rough handling and desiccated by exposure, the tusk, $3 \mathrm{ft}$ long and up to $7 \frac{1}{2} \mathrm{in}$. in diameter, rivals the largest of those displayed in the American Museum's Hall of Mammals and their Extinct Relatives. It was formally delivered to Richard Parr Whitfield, curator of the Museum's Department of Paleontology.

A few days after the presentation, Whitfield went to examine the site. Beneath the Harlem River salt marsh he found 4 to $6 \mathrm{ft}$ of meadow sod and silt filled with roots. Just beneath this layer was $12 \mathrm{ft}$ of what he described as "incipient peat." In addition to grasses, the peat contained grass seeds, sedges, nuts, and beetle wings. The top of the peat layer held stumps and roots of forest trees, as well as wood fragments. Below the peat, 18 to 20 in. of sandy clay rested directly on Inwood marble, the bedrock base of the area. The butt of the tusk had been embedded in the sand and the remainder in the peat. Neither the tusk nor the peat seemed to have been transported to the site by water or ice: they were found just as they had originally been deposited (Whitefield 1891).

Whitfield's description of the site fits well with what is known about the recent geology of New York City. Some 17,000 years ago, a large fresh water lake began to form in front of the retreating glacier, trapped in the south by the terminal moraine, a natural dam composed of debris pushed 
along by the glacier and released from it when the ice melted. The sandy clay at the site was deposited on the lake bottom. As the edges of the lake filled in, vegetation took over-first grasses, and then trees, a classic example of succession. The lake drained when the natural dam at The Narrows was breached; eventually the Harlem River valley, the Hudson River valley, and all the low areas of the region were flooded by the sea, which reached its present level in this area about 6,600 years ago. It is about this time that the estuarine waters Harlem and Hudson met, providing the site's youngest layer, the salt meadow.

Did the mastodon die on the spot? Or had the tusk been wrenched from its socket during a ferocious but nonfatal battle at the site? The tusk eventually settled through the peat until it came to rest on the sand below, but no other bones were found during the excavation. We will probably never know for certain when this took place, but we can make some good guesses even without radiocarbon dating. This area was covered by glaciers 17,000 years ago, so the mastodon is younger than that. The lake eventually drained about 13,000 years ago, and the area remained above water until the sea encroached. The tusk was found in the peat, so a reasonable guess is an age of 13,000 or 14,000 years. Within the next few thousand years, many of North America's large mammals, as well as the mastodons that roamed the spruce forests of what is now New York, had become extinct.

The last discovery of a mastodon occurred in April 1925 about $1 / 2$ mile south of the canal and 100 feet from the ditch dug in 1885. Although the ongoing construction for an apartment house destroyed part of the skeleton, the lower jaw and some teeth of a young mastodon were saved. The fossils were found in a former peat bog, $21 \mathrm{ft}$ below the sidewalk level, on the northwest corner of Seaman Avenue and Dyckman Street. The news spread through the neighborhood and hundreds of people gathered to see this ancient inhabitant of Inwood. The fossils were put on temporary display at the construction site, where several of the teeth were stolen. First, it was the milkman who took a tooth saying "I want this for Hazel. It'll be a corking thing for the whatnot." Soon others raided the teeth (New York Times 1925). Only three were left, but following a plea for their return, two of the molars were brought to the American Museum, and at least one person received $\$ 10$ for its return after the museum advertised that they were willing to pay. The recovered fossils were presented to the American Museum by the owner of the property and they were put on display for a short time. The museum's catalog card states that the fossils were "secured through the courtesy of contractors, city building inspectors and other friends" (Berger 1956). Other fossil mastodon parts have been found in The Bronx, Brooklyn, and Staten Island. Outside of the city, they grow more numerous, even those that have been dredged up by fishermen from the continental shelf (Schmeck 1966).

Not all mastodon bones have a known provenance. Take the person who was driving through Central Park and almost hit a 5 -ft bone lying partly on the road. The specimen was labeled "Mast" and had a number so he called the American Museum to find out if they had any missing specimens. He also put an advertisement in the New York Times in an attempt to find the owner (New York Times 1958). Did the bone fall out of the car by accident or was it pushed out in attempt to get rid of it (perhaps an unwanted inheritance)? There were no responses to the ad. People sometimes use the park to rid themselves of unwanted items, for instance, like the slab of black Burgess Shale with their obvious fossils I found one day.

One of the obvious aspects of all these incidents and discoveries is that people come to a museum to inquire about their mastodons as well as other large fossils. It is evident that all the major research about these large animals takes place in independent museums or museums associated with universities. The functions of museums are threefold: have collections which they catalog; study the collections; and educate the public through exhibits, field trips, and lectures.

Not all mastodons in New York are natives; some come for a short visit and others stay permanently. Perhaps the first fossil to be seen in New York City was a mastodon tooth, originally found in Claverack, a town in the Hudson Valley about $30 \mathrm{mi}$ south of Albany, in 1705. Its discovery caused quite a sensation in New York and throughout New England with much correspondence between clergy, doctors, and politicians about the nature and meaning of an obvious tooth weighing almost $4 \mathrm{lb}$ (Semonin 2000, pp. 34; Mather 1714-1716). Speculation was in full bloom about what type of animal such a tooth could belong to. Although there were many suggestions, from fish to whale, two Puritan clergymen, Edward Taylor and Cotton Mather, helped popularize the discovery and attributed the fossil to a race of giants mentioned in the bible and destroyed by The Flood (Semonin 2000, pp.15-17).

The next extraterritorial mastodon to make its way to the city was found in 1845 north of the city in the Newburgh area where numerous mastodons have been found over the years (Osborn 1926). The summer of 1845 was very dry, causing ponds and bogs to dry up. Taking advantage of the situation, the local farmers easily dig up the peat and marl, which made an excellent fertilizer for their fields.

One of the farmers, Nathaniel Brewster of East Colderham near Newburgh, New York, hired a group of workmen to dig out the peat. After reaching a depth of about $3 \mathrm{ft}$ below the surface, they struck a hard object. Continual digging exposed a 4-ft-long skull bearing a pair of gently curving tusks. 
Eventually, an almost perfectly preserved skeleton was revealed, standing upright in the bog where it sank thousands of years ago (Preston 1986, p. 135-136).

In early 1846, John Warren, a wealthy professor of anatomy at Harvard College, bought the mastodon for $\$ 5,000$ and his son-in-law took it on tour where it was exhibited at the Minerva Rooms on Broadway in New York City, an exhibition and entertainment facility. It was then packed up and shipped to Boston where it was mounted for display in Warren's museum. Several famous nineteenth century scientists came to see the mastodon, including Louis Agassiz and Sir Charles Lyell. This was the beginning of a collection that Warren made of mastodons and their relatives from many parts of the United States as well as Europe. In fact, his museum specimens in comparative anatomy, osteology, and paleontology were considered to be one of the richest private collections in the world.

When he died in 1856, his will stipulated that his bones were to go to the Harvard Medical College and the bones of the celebrated mastodon to his family. The medical college indicated that they "wouldn't mind swapping the bones with his family as mastodons are scarcer than men in these peculiar institutions" (New York Times 1856). Later, in 1906, the trustee of the collection Timothy Dwight wrote a letter to the president of the American Museum of Natural History, Henry Fairfield Osborn, suggesting that the collection might be for sale under certain conditions. Extinct elephants were Osborn's passion and he left for Boston the night of the same day he received the letter. The next morning he and Dwight inspected the specimens and they settled on $\$ 30,000$ for the entire collection. Not long after that Osborn called J.P. Morgan and asked if he could send over a check to the museum for $\$ 30,000$ to cover the cost of the entire collection. Morgan easily agreed. Those were the days. Osborn conducted his research over a span of 50 years writing his massive two-volume work Probiscidia in 1936, which weighed $40 \mathrm{lb}$ and reportedly cost the museum over $\$ 250,000$ (Preston 1986, p. 138). Today, visitors to the American Museum of Natural History can see the Warren mastodon standing majestically at the entrance to the Hall of Mammals and behind it numerous examples of extinct elephants, which can also be seen on the internet at www.amnh.org/exhibitions.

One of the interesting aspects of the preservation of these elephants is what determines whether the skeleton does or does not remain intact. While excavating his first mastodon, Peale remarked on how widely scattered the bones of the animal were (Sellers 1980, p 302) whereas those of the Warren Mastodon were almost in place, although they were preserved in the same type of environment. Taphonomy is the study of what happens to an animal or plant between the time it dies and until its discovery as a fossil. Fossilization involves a number of processes including the action of scavengers and decomposition, after-death transportation, burial, compaction of sediments, and chemical changes affecting the remains of the organism.

In a way, it is a surprise that no mastodon bones have been reportedly found on Manhattan island for the last 80 years, given the fact that so much construction has taken place and that skeletal parts are found more or less regularly north of the city. Part of the reason may be that some of the construction sites have not occurred in the environments favorable for the preservation of these animals. How much is attributed to the lack of looking in (or ignoring) the "dirt" that covers the bedrock is hard to say. In the last 30 years, laws have been strengthened to preserve archeological (and fossil) material in excavations but paleontological treasures have yet to be revealed. Perhaps this is because of the fact that early settlement sites were built directly on the natural surface or slightly below it or on filled wetlands. In some cases, it could be the sampling techniques such as small split spoon cores which would not "see" a mastodon or an archeological site.

The mastodon belonged to a line of proboscideans, or trunk bearers, which expanded its range from the Old World, where it originated, to the New World some 15 million years ago. By two million years ago in North America, only Mammut americanum, the American mastodon, survived. Mastodon remains have been found from Alaska to Florida but are prevalent in the eastern United States, where the creatures inhabited dense, spruce-dominated forests. Up to $10 \mathrm{ft}$ tall at the shoulder, with a shaggy brown coat and upward-curving tusks, the American mastodon browsed on coarse vegetation such as spruce cones and twigs, leaves, and mosses.

So why did these animals as well as mammoths, sabertoothed tigers, and giant beavers, among others, go extinct? The answer is not known for sure. Certainly, vegetation changed as climate warmed and glaciers receded, which is recorded in many wetlands, past and present (Miller and Nester 2000), documenting an ecological change resulting, some say, in the megafauna collapse. It has also been strongly suggested that humans contributed to their demiseas they migrated into the ice-free landscape they hunted the animals into extinction (Martin and Wright 1984). Others have suggested that these migrating people brought one or more diseases with them contributing to their downfall (http://www.amnh.org/biobulletin).

Even in Manhattan, we recognize that extinction is forever and how different the animals in the world were a relatively short time ago compared to nowadays. In their loss, there are lessons for the present time when so many plant and animal species are being lost as a result of climate change and interference by people. 


\section{References}

Baskerville CA. Bedrock and Engineering Geologic Maps of New York County USGS Miscellaneous Investigations series I-2306, 2 sheets 1994.

Beach WMD. The remains of a Mastodon found on Long Island. New York Times 1858:p. 2, April 9.

Berger M. About New York. New York Times 1956: p. 51, April 20.

Cozzens I. A geological history of the New York or Manhattan Island. New York: W. E. Dean; 1843. 114 pp.

Hartnagel CA, Bishop SE. Mastodons, mammoths and other Pleistocene mammals of New York State. New York State Museum Bulletin 1922;241-242:1-110.

Haynes G. Mammoths, mastodons, and elephants: Biology, behavior and the fossil record. New York: Cambridge Press; 1991. 413 p.

Hollick CA. A recent find of drift fossils at Prince's Bay (Staten Island, New York). Proceedings, Staten Island Institute of Arts and Sciences 1893;4:2.

Hollick CA. The museum collection of fossil plants. Bulletin of the New York Botanical Garden 1908;9:214-26.

Martin PS, Wright HE, editors. Pleistocene extinctions: A prehistoric revolution. Tucson: University of Arizona Press; 1984.

Mather C. An extract of several letters from Cotton Mather, D.D. to John Woodward, M.D. and Richard Waller, Esq; S.R. Secr. Philosophical Transactions 1714-1716;29:62-71.

Miller NG, Nester PL. Paleoecology of a late Pleistocene wetland and associated mastodon remains in the Hudson Valley, southeaster New York State. In: Greb SF, DiMichele WA, editors. Wetlands through time; Geological Society of American, Special Paper 399; 2000. p. 291-304.
New York City Department of Parks. Baisley Pond Park Historical Sign; 2001. 1 p.

New York Times. The Will of the Late Dr. Warren of Boston. New York Times; June 3, 1856. p. 2.

New York Times. Manhattan Yields Mastodon's Bones. New York Times; March 26, 1925. p. 15.

New York Times. Who Lost 5-Foot Bone? New York Times; October 30, 1958. p. 10.

Osborn HF. Mastodons and Mammoths of North America. American Museum of Natural History, Guide Leaflet No. 62; 1926. $46 \mathrm{pp}$.

Preston D. Dinosaurs in the Attic. New York: St. Martins Press; 1986.

Schmeck H Jr. Mastodon teeth are found offshore. New York Times; November 27, 1966. p. 40.

Sellers CC. Mr. Peale's museum. New York: W.W. Norton and Company; 1980. 370 pp.

Semonin P. American monster. New York: New York University Press; 2000. $400 \mathrm{pp}$.

Simpson GG. The beginnings of vertebrate Paleontology in North America. Proc Am Philos S 1942;86(1):130-88.

Simpson GG, Tobien H. The rediscovery of Peale's Mastodon. Proc Am Philos So 1954;98(4):279-81.

Van Brimmer BA. Beach Wooster. In: American National Biography, vol. 2. New York: Oxford University Press; 1999.

Viele EL. Sanitary and Topographic Map of the City and Island of New York; 1865.

Whitfield RP. Mastodon remains on New York Island. Science 1891;18(463):342.

Yockelson E. Mr. Peale and His Mammoth Museum. Proc Am Philos Soc 1992;136(4):487-506. 